\title{
Kabir, Rahim and Biharilal's Dohas in Translation
}

Ram, K. S. (Trans.). 2019. Dohavali: Popular Couplets of Kabir and Others. Chennai: Notion.

Reviewed by RAGINI RAMACHANDRA

First published in 1986 by Writers Workshop, Kolkata, the Dohas of Kabir and others re-appear here in a new format augmented by additional features such as a literal rendering of the original text from Hindi into English, brief footnotes and commentary by the translator to make the present version "more reader-friendly".

The book is aptly dedicated to the memory of the author's grandmother, Jambur Mylariah Savitramma (1907-1991), "a village bard, largely self-taught, who wrote songs in Kannada and a longish ballad on Lord Rama recited devoutly in many homes on Saturdays". That she should have composed hundreds of panegyric verses rooted in the philosophy of the Srimad Bhagawata Purana and that All India Radio (Akashwani) should have bracketed her with the Women Haridasas of Karnataka in a recent broadcast affirms the vitality of the oral tradition in the Indian context which many others too from small hamlets, like this remarkable lady, have helped keep alive.

That Ram should have felt the urge to re-visit the Dohas after over three decades testifies to the irresistible appeal, they must have had for him. In his own words they enjoy a stature comparable to proverbs and have over the centuries become a part of everyday parlance. Quoted in the Hindi-belt countless times every day at home and in the street, they have shaped the popular culture in India, he observes in his incisively written Preface. Part of school curriculum, the subject-matter of the dohas, however, goes beyond the school level to impinge upon the consciousness of even the adult reader as some western 
classics like Alice in Wonderland or Gulliver's Travels might do, he concludes.

Ram's Note on Translation at the beginning of the volume most pertinently invokes the great Sanskrit rhetorician Anandavardhana of the 9th century AD to define how, faithful translation happens "when the original art-experience (dhvani) is re-created in a different language" (p.12). That the translated version here offers an experience even if it be through a short format such as dohas (two-lined rimed couplets) is a measure of the translator's success. His allusions to various other sources such as the Vedas, the Bhagavad Gita, the Srimad Bhagavatam and the Bible to find echoes and parallelisms are impressive as they broad base the theme and also illustrate the fruitfulness of a comparative approach.

Of the 51 dohas included here, a majority of them are by Kabir and the rest by Rahim and Biharilal. What is common to all these three saint-poets is their contemplative nature, a strong predilection for reflecting on the nature of life, universe, humanity, Man-God relationship, etc.etc. While the theme is by and large religious, the language is innocuously simple, the style amazingly terse and pithy. In fact, part of the fascination lies in the epigrammatic style that is reminiscent of vachana or dasa sahitya in the Indian bhakti tradition. Even profound truths are put across through homely images, similes and metaphors. Analogies drawn from every-day life lend an irrevocable authenticity while trenchant logic defies all scepticism. Worldly wisdom is not lacking either but found interspersed with spiritual aspirations.

If Kabir meditates on the power of Ram-naam, the Will of God, true devotion, bonding with sages, unity of Creation, Guru-shishya relationship, etc, Rahim and Biharilal examine the practical aspects of life without of course eschewing the spiritual element. Self-deprecation born of intense humility 
coupled with infinite faith in God characterizes the dohas of Kabir in particular. Wit, humour and sarcasm are employed most effectively and unobtrusively, while the talking voice of the poet is preserved delightfully even in English translation. To cite a few random examples:

Ablutions, Kabir, are purposeless, if th' mind preserve its mess. The fish washes continually; it stinks nonetheless!

- Kabir (p.77)

Finding something big, Rahim, the small don't disdain.

Where a needle is needed, think, can a sword step in?

$$
\text { - Rahim (p.79) }
$$

Sage union cannot amend someone foul within.

Asafoetida is pungent still, stored in a camphor tin.

- Biharilal (p.85)

Thanks to Ram, what might have been a closed book to nonHindi readers has been made available in English in an idiom that sounds natural and spontaneous. To partake of the wealth that Kabir's inner eye (jnana-chakshu) could behold in the couplet quoted below for instance is one of the chief benefits that the reader ought to be particularly grateful for:

Any eye can see, Kabir, the drop that joins the sea.

The sea intrinsic in the drop; only the blessed see! (p.103)

Finally, Notion Press deserves to be congratulated on bringing out an aesthetically appealing, yet reasonably priced volume that contains such nuggets of wisdom!

$* * *$

\section{Cite this work:}

RAMACHANDRA, RAGINI. 2020. Kabir, Rahim and Biharilal's Dohas in Translation. Review of Dohavali: Popular Couplets of Kabir and Others, by Ram, K. S. (Trans.). Translation Today, Vol. 14(1). 143-145.

DOI: $10.46623 / \mathrm{tt} / 2020.14 .1 . \mathrm{br} 5$ 